\title{
MENARIKAN ILUSTRASI: PERKEMBANGAN SISTEM NOTASI VERNAKULAR UNTUK TARI MELAYU
}

\section{(Dancing the Illustrations: Development of Vernacular Notation System for Malay Dance)}

Leng Poh Gee*

lengpg@yahoo.com

Fakulti Muzik dan Seni Persembahan, Universiti Pendidikan Sultan Idris.

Mumtaz Begum Aboo Backer

mumzie@usm.my

Pusat Pengajian Seni, Universiti Sains Malaysia.

Pengarang koresponden (Corresponding author): *

Rujukan artikel ini (To cite this article): Leng Poh Gee \& Mumtaz Begum Aboo Backer. (2021). Menarikan ilustrasi: Perkembangan sistem notasi vernakular untuk tari Melayu. Melayu: Jurnal Antarabangsa Dunia Melayu, 14(2), 219-238. http:// doi.org. 10.37052/jm.14(2)no4

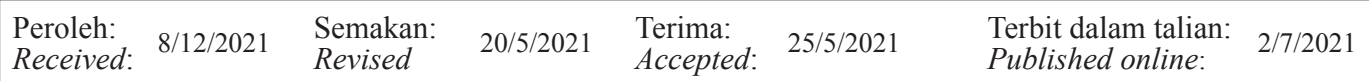

\begin{abstract}
Abstrak
Pengamalan sistem notasi tari vernakular yang dicipta khas, digunakan dan diedarkan dalam kalangan komuniti pengamal pelbagai genre tari Melayu tempatan menjadi salah satu alternatif dalam pengukuhan dokumentasi dan pelestarian tari sejak 1940an, untuk kedua-dua domain akademik (D’Cruz, 1979; Mohd Ghouse, 1979) dan masyarakat umum (Ahmad Omar, 2005; Daud, 1965). Artikel ini menghuraikan keberadaan sistem notasi vernakular tari Melayu yang berlandaskan tiga jenis pendekatan ilustrasi, iaitu (1) notasi tapak kaki, (2) notasi posisi penari, serta (3) pelan pola lantai. Dapatan diperoleh daripada analisis skor pergerakan berdasarkan pengetahuan Labanotasi serta daripada sorotan literatur dan pemerhatian peserta.
\end{abstract}

(C) Dewan Bahasa dan Pustaka. 2021. This work is licensed under the term of the Creative Commons Attribution (CC BY) (http://creative commons.org/licenses/by/4.0/)

ISSN 1675-6460 e-ISSN 2682-8049 
Artikel ini ingin mengisi kekosongan pembangunan dan kepenggunaan sistemsistem notasi vernakular yang belum diwacanakan dalam konteks pengajian dan penyelidikan tari tempatan, serta menunjukkan peranan notasi vernakular dalam industri seni tari semasa.

Kata-kata kunci: notasi tari, notasi vernakular, tari Melayu

\begin{abstract}
The use of vernacular dance notation systems that are specifically created, used and circulated among the practitioners of various local Malay dance genres have become one of the alternatives for dance documentation and preservation since the 1940s, for both the academic domain (D'Cruz, 1979; Mohd Ghouse, 1979) and general public (Ahmad Omar, 2005; Daud, 1965). This article recognizes the existence of vernacular notation systems of Malay dance that are based on three categories of illustration, namely: (1) footprint notation, (2) notation of dancers' positions, and (3) floor plan. The findings were obtained from the movement score analysis based on Labanotation, as well as from literature review and participant observation. This article seeks to fill in the gap of the development and usage of vernacular notation systems that have not been explored in the context of local dance studies and research. The article also points out the roles of vernacular notation in the current dance industry.
\end{abstract}

Keywords: Dance notation, vernacular notation, Malay dance

\title{
PENGENALAN
}

Guest (1984: XIV) mendefinisikan notasi tari sebagai "penterjemahan daripada pergerakan empat dimensi (masa menjadi dimensi keempat) kepada bentuk tanda bertulis pada kertas dua dimensi”. Berdasarkan definisi ini, notasi merujuk dokumentasi dua dimensi terutamanya kertas yang berupaya menerangkan pergerakan dan membolehkan pergerakan dipersembahkan semula mengikut tatatertib yang termaktub. Dokumentasi ini juga dikenali sebagai skor dan lazimnya terdiri daripada pelbagai bentuk ilustrasi seperti simbol dan foto. Dokumentasi ini biasanya dilakukan oleh institusi atau komuniti pengamal atau peminat tegar sesuatu tari, yang ingin mentranskripsikan gerak kepada bentuk dokumentasi untuk pelbagai tujuan, seperti penyelidikan, pengajaran dan pembelajaran, pelestarian serta pemugaran.

Seperti notasi muzik, sistem notasi tari terdiri daripada koleksi simbol yang telah diiktiraf, dipersetujui dan standard untuk membolehkan komunikasi yang berkesan 
dalam kalangan pembaca skor. Notasi tari merupakan sistem ilustrasi grafik yang spesifik dan dapat merakamkan pergerakan secara teknikal dengan kuantiti yang termaktub. Kuantiti di sini merujuk angkubah matematik dan membolehkan pembaca melakonkan semula pergerakan dengan mengambil kira darjah sudut arah, ketinggian aras, durasi masa yang diperlukan, serta bahagian badan yang terlibat. Pelbagai jenis sistem notasi tari telah dicipta dan digunakan sejak awal abad ke15 lagi, untuk mencatatkan produksi persembahan besar-besaran yang dianjurkan oleh istana-istana Eropah. Walau bagaimanapun, semua sistem notasi itu telah diluputkan (Guest, 1984 \& 2005; Royce, 1977), disebabkan sifat notasi yang terlalu idiosinkratik untuk digunakan bagi semua tari, terlalu rumit untuk diingat dan digunakan, atau terlalu mengambil mudah untuk merakamkan ketepatan tari (Laban, 1946, dlm. Royce, 1977: 44). Guest (1984) turut menekankan bahawa tiada sistem notasi yang sempurna. Kekurangan kefahaman yang mendalam terhadap sistem notasi sedia ada serta kehilangan kesabaran untuk melakukan eksperimen, penggunaan sesuatu sistem notasi yang berulangan merupakan faktor kegagalan bagi penerusan sesuatu sistem notasi tari. Secara umumnya pada masa kini, sistem notasi tari yang lazimnya dianggap sebagai notasi yang formal dan diguna pakai dalam domain akademik ialah Labanotasi dan Notasi Benesh. Labanotasi merupakan salah satu subjek wajib dalam program Ijazah Sarjana Muda Tari yang ditawarkan oleh institusi pengajian tinggi awam Malaysia, seperti Akademi Seni Budaya dan Warisan Kebangsaan, Universiti Malaya dan Universiti Pendidikan Sultan Idris. Oleh yang demikian, Labanotasi mempunyai kedudukan yang eksklusif kerana sering dikaitkan dengan pengajian akademik. Notasi Benesh pula ialah sistem notasi formal yang lazimnya digunakan oleh pengamal seni balet, khasnya oleh The Royal Academy of Dance (RAD) yang berpusat di UK. RAD merupakan lembaga pentauliahan tenaga pengajar balet dan pengiktirafan penggredan balet klasik yang sangat popular pada peringkat antarabangsa. RAD menggunakan Notasi Benesh sebagai notasi rasmi untuk mentrankripsikan sukatan tari balet mereka. Perkembangan Notasi Benesh di Malaysia adalah amat terhad kerana pembelajaran Notasi Benesh bukanlah sesuatu yang wajib atau syarat bagi pentauliahan tenaga pengajar dan ujian penggredan RAD.

Kedua-dua Labanotasi dan Notasi Benesh dianggap sebagai sistem formal dan sistematik dalam dunia pengajian tari. Namun begitu, artikel ini menekankan pembangunan pelbagai ciptaan sistem notasi tari yang "tidak formal", tersendiri dan khas untuk merakamkan tarian Melayu. Penulis mengenali sistem notasi tersendiri ini sebagai notasi vernakular, kerana sistem notasi ini khas dicipta, digunakan dan diedarkan dalam kalangan komuniti penggiat seni yang tertentu sahaja. Dalam pada itu, pengetahuan Labanotasi berpengaruh dalam perkembangan sesetengah notasi 
vernakular tari Melayu, seperti notasi vernakular yang diasaskan oleh Yayasan Warisan Johor. Namun begitu, tiada pengaruh pengetahuan Notasi Benesh yang dapat dikesan di dalamnya.

Walaupun sistem notasi vernakular ditemui dalam pentranskripsian gerak-gerak sukan, senaman fizikal, yoga, seni mempertahankan diri dan sebagainya, artikel ini hanya tertumpu pada hubung kait antara notasi vernakular dengan tari Melayu sahaja untuk memahami usaha meneruskan keberlangsungan tarian sebagai warisan budaya tidak ketara yang lazimnya disampaikan secara lisan. Sistem notasi vernakular tari yang dicipta bukan sahaja mengandungi daya kreativiti yang memenuhi keperluan fungsi dasar notasi, tetapi juga mengambil kira aspek keindahan paparan dan susunan tanda-tanda grafik yang praktikal, supaya indah dibaca dan mesra penggunaannya. Dalam pada itu, penerangan fenomena penciptaan dan penggunaan notasi vernakular dapat menunjukkan tahap kebijaksanaan dan fleksibiliti pengamal tari Melayu yang tinggi dalam usaha mengintegrasikan pelbagai pengetahuan daripada kinesiologi, analisis gerak, estetik, semiotik, kesejarahan, sehinggalah pengajian budaya untuk menghasilkan sesuatu sistem notasi vernakular.

\section{ILUSTRASI SEBAGAI PILIHAN UTAMA TRANSKRIPSI TARI}

Manusia yang sedang menari boleh "dibekukan" dan diperhatikan seperti arca pada masa-masa yang berbeza melalui pelbagai ilustrasi seperti foto, lukisan, tapak kaki dan bentuk manusia lidi (stick figure). Paparan posisi gerak secara statik ini merupakan cara popular dalam notasi tari. Pembaca skor boleh meniru gerak yang diilustrasikan secara berasingan dan kemudiannya menggabungkan gerak-gerak itu dengan mengikut susunan.

Walau bagaimanapun, tari yang melibatkan pelbagai elemen koreografi dan sentiasa bergerak adalah sukar "dibekukan" seperti arca. Dalam keadaan yang kompleks ini, kebanyakan pencatat tari atau notator tidak berniat untuk menotasikan seluruh gerak pada badan, tetapi hanya memilih bahagian badan tertentu yang ingin dinotasikan sahaja. Dengan erti kata lain, hanya ciri-ciri dominan sesuatu tari yang penting, menonjol dan istimewa dipilih untuk dinotasikan. Sebagai contoh, ciri dominan Zapin terletak pada manipulasi langkah kaki atau foot work; tari Makyung dan Asyik memberikan penekanan kepada pergerakan mudra ${ }^{1}$ pada bahagian tangan dan lengan; manakala keistimewaan Joget Gamelan terletak pada manipulasi peralatan tangan seperti kipas dan selendang. Oleh itu, sistem notasi vernakular tari Melayu adalah unik dan sangat khusus untuk memenuhi keperluan tari-tari yang berbeza. 
Kebanyakan sistem notasi vernakular dibangunkan dengan menggunakan ilustrasi grafik yang berbentuk dua dimensi. Berdasarkan kaedah analisis pergerakan daripada pengetahuan Labanotasi, artikel ini menyusun sistem-sistem notasi vernakular mengikut tiga pendekatan ilustrasi grafik, iaitu (1) notasi tapak kaki, (2) notasi posisi penari, serta (3) pelan pola lantai. Ketiga-tiga pendekatan notasi ilustrasi ini dibincangkan dengan merujuk skor-skor yang pernah dicetak sama ada untuk tujuan penyelidikan (seperti tesis), pengkomersialan (seperti penjualan naskhah), atau simpanan arkib (seperti laporan). Walaupun sistem notasi vernakular yang berbeza memiliki konsep kinesiologi, estetik, struktur dan peraturan yang berbeza, namun fungsi dasar bagi ciptaan sistem notasi vernakular adalah sama, iaitu adalah untuk membolehkan sesuatu tari dapat dipersembahkan semula. Keutamaan artikel ini adalah untuk menerangkan fenomena kepenggunaan pelbagai jenis sistem notasi vernakular dalam kalangan komuniti pengamal tari Melayu tempatan, dan seterusnya mencadangkan peranan dan kerelevanan sistem notasi vernakular yang terkini.

\section{Notasi Tapak Kaki}

Secara umumnya, melangkah merupakan gerak asas bagi kebanyakan tari tradisional. Kemahiran melangkah menunjukkan kekemasan teknik pembawaan dan pemindahan berat badan seseorang penari. Dalam persembahan Kabuki Jepun, jambatan hanamichi ${ }^{2}$ merupakan satu jalan laluan yang semata-mata menguji persembahan gaya berjalan yang spesifik. Dalam konteks tari Melayu, penggayaan melangkah adalah penting berpadanan dengan genre muzik irama sama ada Joget Gamelan, Asli, Inang, Joget atau Zapin. Cara gaya melangkah dalam tari Melayu mencerminkan pengkhususan gender, serta ketelitian yang bersesuaian dengan kostum. Dengan itu, notasi tapak kaki adalah sesuai untuk menotasikan tari-tari yang mempunyai banyak langkahan.

Yayasan Warisan Johor ${ }^{3}$ (YWJ) yang ditubuhkan di bawah kerajaan negeri Johor Darul Ta'zim bertujuan untuk memartabatkan warisan sejarah, seni dan budaya negeri Johor, demi mencapai pembangunan yang holistik dan menyeluruh dalam seni budaya dan ekonomi tempatan. YWJ ingin memantapkan jati diri sebagai warga Johor melalui pemeliharaan dan penyebaran kegiatan warisan negeri Johor. Dengan berlandaskan tujuan tersebut, Zapin telah diangkat sebagai salah satu amalan kegiatan yang penting untuk melambangkan identiti warga Johor. Negeri Johor yang dipercayai merupakan pusat pengembangan tari Zapin, dan mempunyai bilangan jenis Zapin yang banyak sekali dijumpai di daerah-daerahnya. 
Jadual 1 Senarai Zapin yang telah diselidik oleh YWJ. (YWJ, 2013).

\begin{tabular}{|l|l|l|l|}
\hline Bil. & Nama Jenis Zapin & Daerah & $\begin{array}{l}\text { Tahun } \\
\text { Selidik }\end{array}$ \\
\hline 1. & Zapin Melayu Johor & Johor Bharu & 1996 \\
\hline 2. & Zapin Tenglu & Mersing & 1999 \\
\hline 3. & Zapin Pulau & Mersing & 1999 \\
\hline 4. & Zapin Pekajang & Johor Bharu & 2002 \\
\hline 5. & Zapin Parit Mastar & Pontian & 2002 \\
\hline 6. & Zapin Sri Bunian & Pontian & 2002 \\
\hline 7. & Zapin Tanjung Labuh & Batu Pahat & 2002 \\
\hline 8. & Zapin Kores & Batu Pahat & 2002 \\
\hline 9. & Zapin Putar Alam & Muar & 2004 \\
\hline 10. & Zapin Padang Sari & Batu Pahat & 2006 \\
\hline 11. & Zapin Dayung & Batu Pahat & 2006 \\
\hline 12. & Zapin Lenga Batu 28 & Muar & 2009 \\
\hline 13. & Zapin Mahpom & Muar & 2009 \\
\hline 14. & Zapin Pat Lipat & Muar & 2009 \\
\hline 15. & Zapin Mahpom Versi (Tua) dan & Muar & 2010 \\
\hline 16. & Zapin Kores Versi 2 & Batu Pahat & 2010 \\
\hline 17. & Zapin Daeng Mato'nak & Pontian & 2010 \\
\hline 18. & Zapin Chokoh & Pontian & 2010 \\
\hline & & & \\
\hline
\end{tabular}

The Johore Malays, in particular, attribute the development of Zapin Arab and Zapin Melayu to a dance tradition of the Hadhramis (the Arabs of Hadhramaut) who first brought the Hadhrami tradition to the Malay area. (Mohd Anis, 1993: 5)

YWJ memulakan program pemugaran Zapin dengan perancangan yang amat strategik sejak pertengahan 1990-an (Mohd Anis, 2014), ketika persembahan tradisional Zapin hampir dilupakan oleh masyarakat Johor. YWJ menganjurkan pelbagai aktiviti Zapin dari semasa ke semasa, seperti kelas latihan, festival, seminar, bengkel, perkhidmatan kejurulatihan dan lain-lain lagi demi meneruskan kelangsungan warisan tari Zapin seiring dengan pencapaian misi dan visi YWJ. Setelah usaha mencapai hampir tiga dekad, Zapin kini sangat popular pada semua peringkat, daripada peringkat sekolah rendah sehinggalah kepada badan-badan berkanun negeri, dari kampung sehinggalah ke bandar tanpa mengira kaum dan bangsa. Kini terdapat sekurang-kurangnya 18 jenis Zapin yang telah dikaji dan 
didokumentasikan oleh YWJ (Jadual 1). Para pengasas, pewaris dan pengajar di daerah-daerah yang berkenaan telah diiktiraf sebagai informan atau penyebar seni Zapin yang penting.

Untuk memastikan persembahan langkah adalah asli daripada pengasas, YWJ mengetatkan syarat-syarat dalam pentauliahan jurulatih yang mengajarkan Zapin daripada peringkat pusat negeri sehingga kepada peringkat daerah, serta syaratsyarat untuk pertandingan Zapin anjuran YWJ yang berperingkat. Para jurulatih yang ingin mendapat pentauliahan daripada YWJ perlu menghadiri bengkel-bengkel yang ditetapkan dan lulus ujian kelayakan yang ketat. Dalam bengkel kejurulatihan, skor notasi tapak kaki Zapin diedarkan kepada para calon jurulatih sebagai satu bahan rujukan dan bahan bantuan ulang kaji. Jurulatih yang bertauliah daripada YWJ biasanya mempunyai reputasi yang tinggi terutamanya di daerah-daerah di luar Johor Bahru.

YWJ membangunkan dua sistem notasi tapak kaki yang tersendiri untuk mentranskripsikan Zapin, iaitu (1) Notasi Tapak dan (2) Notasi Vertikal. Keduadua penamaan Notasi Tapak dan Notasi Vertikal bukan nama yang rasmi, namun kedua-duanya dinamakan seperti ini untuk memudahkan perbincangan artikel ini. Skor Notasi Tapak yang diasaskan pada akhir 1990-an telah dijadikan rujukan bagi kejurulatihan, pengajaran dan pembelajaran. Notasi Vertikal yang diasaskan sejak akhir 2000-an dan sedang dibangunkan dengan tujuan untuk menyebarkan seni Zapin pada peringkat antarabangsa. Proses penciptaan dan pembentukan kedua-dua sistem notasi vernakular ini dipantau dan direalisasikan oleh karyawan tamu semasa, Mohd Anis Md Nor, seorang pakar etnokoreologi yang mahir dalam analisis pergerakan struktural berdasarkan Labanotasi (Mohd Anis, 2014). Pembangunan kedua-dua sistem notasi vernakular ini amat dipengaruhi oleh pengetahuan Labanotasi, iaitu menghasilkan satu set simbol yang memaktubkan makna setiap simbol, supaya setiap simbol boleh diguna pakai secara berulangan terhadap semua penotasian Zapin.

Kedua-dua Notasi Tapak dan Notasi Vertikal masing-masing mempunyai peta petunjuk simbol supaya pembaca dapat memahaminya dengan jelas dan dapat mengakses makna simbol (Rajah 1). Petunjuk simbol hanya boleh ditetapkan setelah inventori gerak-gerak Zapin telah siap dilakukan oleh para penyelidik tari YWJ. Dengan adanya senarai inventori unit pergerakan kaki, penggolongan gerak mengikut fungsi dan ciri-ciri dominan boleh dilakukan. Secara umumnya, YWJ menggolongkan gerak kaki Zapin kepada langkah (step), aksi lokomotif yang melibatkan pemindahan berat dari satu titik sokongan ke titik sokongan yang baharu; gestur kaki, aksi bukanlokomotif yang tidak melibatkan pemindahan berat dan berlaku di ruang kinesfera ${ }^{4}$; pergerakan pusing (pivot) yang melibatkan aksi putaran badan di atas paksi vertikal 
(antara langit-bumi); serta lompatan (air work) yang melepaskan sokongan badan daripada graviti supaya boleh berada seketika di ruang udara. Apabila inventori unit-unit gerak mempunyai "rumah" masing-masing, simbol-simbol asas yang mengandungi makna generik direka dan ditetapkan. Dengan menggunakan analogi bahasa, setiap simbol itu adalah seperti huruf yang membentuk perkataan, ayat, dan seterusnya perenggan. Simbol-simbol ini kemudiannya boleh digabungkan untuk membentuk perbendaharaan gerak Zapin.

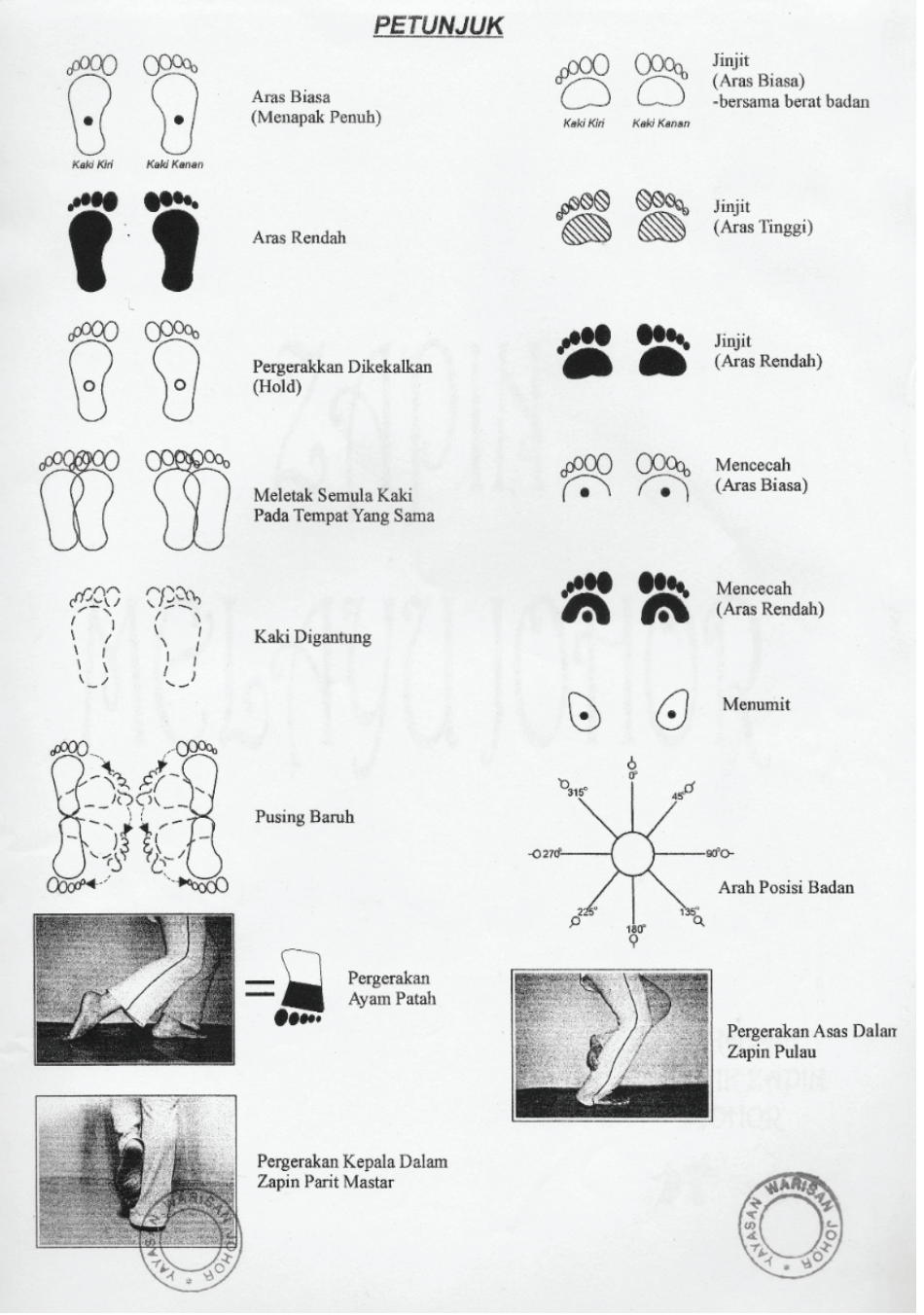

Rajah 1 Petunjuk Notasi Tapak (YWJ, n.d.) 

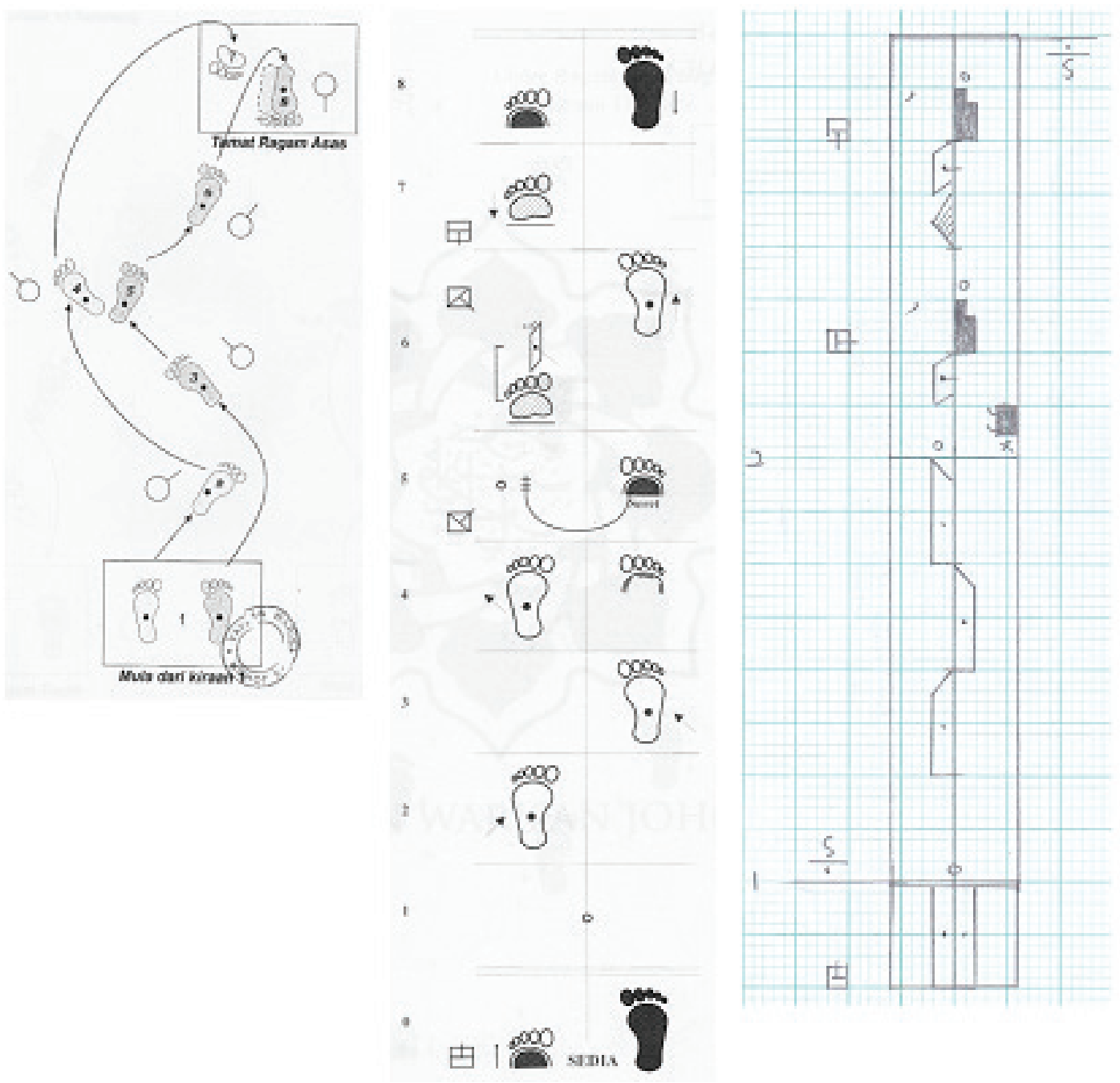

Rajah 2b: Skor Notasi Rajah 2a: Skor Notasi Rajah 2c: Skor Labanotasi Vertikal bagi Ragam Tapak bagi Ragam Asas, bagi Ragam Asas, Zapin Asas, Zapin Melayu Johor Zapin Melayu Johor (YWJ, Melayu Johor (Sumber: (Md. Ismail, Nur Najjwa, n.d.: 1) Koleksi peribadi)

Hamidah, Leng \& Ismail, n.d.: 17) 
Sistem Notasi Tapak digunakan sebagai bahan rujukan yang sahih sejak akhir 1990an dalam kalangan pengikut YWJ. Pada akhir tahun 1990-an, YWJ ingin mengemas kini cara notasi tari Zapin yang lebih berkelihatan "akademik" dengan hasrat untuk menyebarkan Zapin secara lebih meluas, sehingga pada peringkat antarabangsa (Nur Najjwa, emel, 16 April 2015), serta berniat ingin mengukuhkan dokumentasi Zapin demi persediaan bagi permohonan senarai warisan budaya tidak ketara (Intangible Cultural Heritage) sama ada pada peringkat kebangsaan atau antarabangsa (Muhaini, komunikasi peribadi, 18 Okt. 2019). Dalam mengasaskan Notasi Vertikal, kakitangan YWJ yang bertugas perlu menguasai pengetahuan Labanotasi sebelum mereka berupaya meminjam dan mengadaptasikan konsep pergerakan, simbol dan terminologi Labanotasi dalam bentuk yang mesra penggunaannya. Walaupun YWJ telah menotasikan hampir kesemua ragam Zapin yang diselidik dalam bentuk skor Notasi Vertikal, namun belum diterbitkan secara rasmi kerana masih dalam peringkat percubaan dari segi keberkesanannya dan pemurnian susulannya masih sedang dilakukan. Usaha peminjaman dan adaptasi pengetahuan Labanotasi daripada YWJ ini merupakan salah tindakan yang signifikan untuk memindahkan pengetahuan Labanotasi daripada domain akademik kepada golongan umum, walaupun bukan dalam bentuk Labanotasi yang asli.

Untuk membandingkan kesamaan dan perbezaan visual antara skor Notasi Tapak, Notasi Vertikal dan Labanotasi, satu ragam Zapin yang sama ditunjukkan dalam Rajah 2a, 2b dan 2c. Dapat diperhatikan bahawa selain ilustrasi tapak kaki, penambahan pelbagai grafik telah digunakan untuk melengkapkan informasi pergerakan bagi skor Notasi Tapak dan Notasi Vertikal, seperti anak panah yang menunjukkan arah; angka nombor yang menunjukkan kiraan; deskripsi gerak mudah yang menjelaskan keadaan gerak; pin menunjukkan arah badan; dan petak yang mengingatkan bahawa posisi kedua-dua kaki yang dekat. Diperhatikan juga bahawa skor Notasi Vertikal dan Labanotasi mempunyai ciri-ciri peletakan dan perekaan simbol yang mirip. Sistem notasi tapak kaki YWJ amat menekankan kepentingan pada gerak kaki, dan mengandaikan bahawa pembawaan gerak pada lengan, tangan dan badan mengikut sifat "kesemulajadian" (naturalness) atau "kesantaian" sikap tari. "Kesemulajadian" Zapin merujuk pergerakan lengan dan badan yang perlu dihayun untuk mengimbangi manipulasi gerak kaki yang berbunga-bunga, di samping mengekalkan kesederhanaan gerak. Penggayaan gerak ini masih memerlukan tunjuk ajar daripada pengajar yang berpengalaman, kerana tiada sifat "kesemulajadian" yang boleh wujud secara semula jadi - sifat "kesemulajadian" perlu dilatih. 


\section{Notasi Posisi Penari}

Notasi posisi penari sesuai digunakan untuk memerhatikan "spesimen" pergerakan badan secara keseluruhan supaya dapat menirunya. Pembaca boleh melakukan persembahan-semula sesuatu tari melalui imitasi terhadap susunan ilustrasi posisi penari. Cara pembelajaran "bentuk - gerak - bentuk" diamalkan, iaitu bermula daripada meniru posisi penari seperti dalam ilustrasi pertama, kemudian bergerak untuk tujuan meniru posisi penari seperti ilustrasi kedua, dan seterusnya. Gerak yang berfungsi untuk menghubungkan antara dua bentuk dinamakan gerak penghubung, yang bukan sekadar mengisi kekosongan antara bentuk, tetapi memainkan peranan yang penting untuk menunjukkan gaya "kesemulajadian" sesuatu tari, atau lebih dikenali sebagai rasa atau air.

Cara pembelajaran tersebut adalah seperti penghasilan animasi grafik kartun duadimensi yang tradisional, iaitu melalui penerusan penglihatan yang pantas terhadap susunan posisi watak demi menghasilkan ilusi pandangan. Semakin kecil perubahan pergerakan dilakarkan, semakin banyak lukisan diperlukan dan menyebabkan semakin teliti sesuatu susunan pergerakan ditayangkan. Sebagai contoh, untuk menayangkan pergerakan satu pusingan lengkap dengan menggunakan lengan kiri dalam dimensi permukaan roda (wheel plane), seseorang kartunis perlu melukis sekurang-kurangnya lima lukisan, iaitu lengan ke arah bawah (menuju ke bumi) $\rightarrow$ ke arah hadapan tengah $\rightarrow$ ke arah atas (menuju ke langit) $\rightarrow$ ke arah belakang tengah $\rightarrow$ ke arah bawah (menuju ke bumi). Persembahan pergerakan tersebut boleh menjadi lebih halus dan lancar sekiranya jurang gerak antara lakaran didekatkan, iaitu dengan sembilan lukisan daripada lengan ke arah bawah (menuju ke bumi) $\rightarrow$ ke arah $45^{\circ}$ hadapan bawah $\rightarrow$ ke arah hadapan tengah $\rightarrow$ ke arah $45^{\circ}$ hadapan atas $\rightarrow$ ke arah atas (menuju ke langit) $\rightarrow$ ke arah $45^{\circ}$ belakang atas $\rightarrow$ ke arah belakang tengah $\rightarrow$ ke arah $45^{\circ}$ belakang bawah $\rightarrow$ ke bawah (menuju ke bumi).

Contoh yang disebutkan menjelaskan bahawa penghuraian gerak yang lebih halus menyumbang kepada kelancaran gerak yang lebih tepat. Walau bagaimanapun, dengan mengambil kira kos, masa dan pencarian tenaga pakar, lakaran notasi posisi penari lazimnya mempunyai jurang gerak yang besar dan tidak seperti kartun. Oleh itu, pembaca kadang kala perlu "meneka" atau "mencipta" gerak penghubung di antara dua posisi. Sebagai contoh, untuk melaksanakan notasi lengan ke arah atas (menuju ke langit) dan diikuti dengan ke arah bawah (menuju ke bumi), seseorang pembaca boleh melakukan pelbagai gerak penghubung yang mungkin berlaku, seperti lengan di atas boleh diturunkan secara lurus melalui hadapan, sisi, atau belakang, ataupun lengan boleh dibengkokkan dan terus ke bawah melalui laluan tapak tangan 
mendekati ke bahu. Interpretasi atau tekaan gerak penghubung tersebut adalah lebih menepati gaya "kesemulajadian" tari jika pembaca mengenali pengetahuan atau latihan pra-konteks (pre-context knowledge) tari tersebut.

Ilustrasi posisi penari boleh terdiri daripada lukisan, fotografi, manusia lidi (stick figure) dan sebagainya. Rajah ilustrasi itu boleh ditunjukkan daripada pandangan hadapan, belakang, atas, kiri dan kanan, bergantung pada ciri-ciri dominan gerak yang ingin ditekankan oleh notator. Dalam pembentukan notasi posisi penari, proses

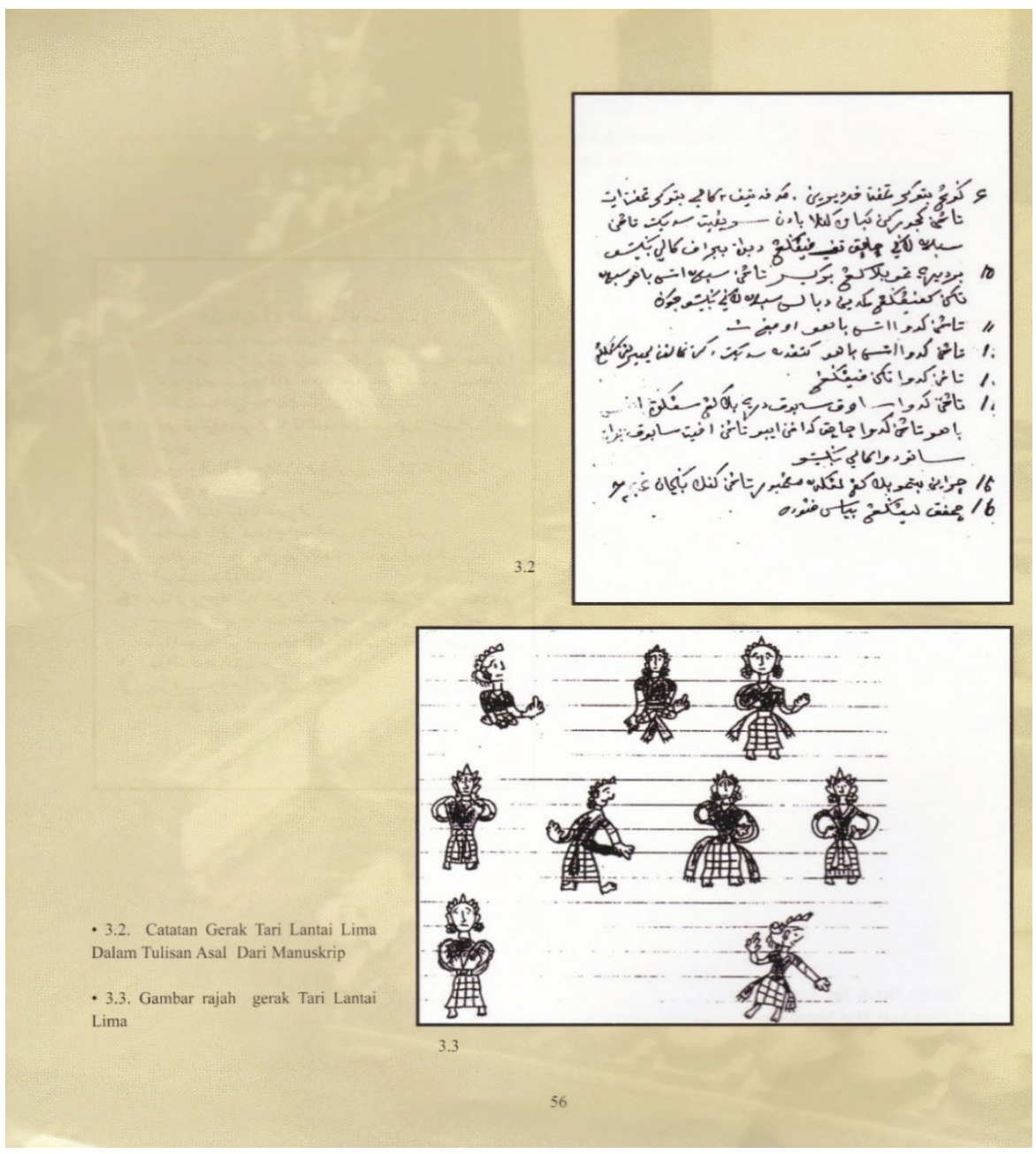

Rajah 3 Petikan Catatan Gerak Tari dan Gambar Rajah Tari.

(Ahmad Omar, 2005: 56) 
inventori unit gerak bukan hanya tertumpu pada satu bahagian sahaja (seperti kaedah notasi tapak kaki), tetapi melihat kepada pergerakan seluruh badan.

Haji Ahmad Omar Haji Ibrahim menghasilkan banyak skor notasi posisi penari untuk Joget Gamelan (2005). Beliau melakukan analisis terhadap manuskrip gerak daripada Almarhumah Duli Yang Maha Mulia Tengku Ampuan Mariam, seorang permaisuri merangkap pencipta sistem notasi vernakular pada 1940-an yang telah berjaya memelihara Joget Gamelan sebagai khazanah warisan seni persembahan istana. Beliau mendokumentasikan gerak melalui kaedah notasi posisi penari berserta dengan deskripsi gerak (Rajah 3) - satu tindakan yang amat bijaksana dan berwawasan pada zaman 1940-an. Berdasarkan hasil analisis daripada manuskrip Tengku Ampuan Mariam, Ahamd Omar telah mengenal pasti sekurang-kurangnya 30 repertoir (daripada 50 repertoir) Joget Gamelan yang mempunyai kedua-dua Catatan Gerak Tari dan Gambar Rajah Tari. Maksud Catatan Gerak Tari yang asalnya ditulis dalam tulisan Jawi adalah seperti yang berikut:

Catatan Gerak Tari mengandungi susunan dan urutan gerak tari dalam satu-satu repertoir daripada permulaan, iaitu daripada gerak sembah buka sehinggalah kepada gerak sembah penyudah. Catatan ini dianggap lengkap dan akan memudahkan untuk kita mengingati gerak tari dalam satu-satu repertoir. Tidak semua repertoir mempunyai catatan tentang gerak tari. (Ahmad Omar, 2005: 53)

Gambar Rajah Tari pula merujuk:

Terdapat beberapa gambar rajah dalam bentuk lukisan tentang gerak dalam manuskrip tersebut. Walaupun tidak lengkap dan terperinci, tetapi boleh difahami tentang bentuk gerak yang dimaksudkan dalam satu-satu repertoir. Tidak semua repertoir ada catatan gambar rajah. (Ahmad Omar, 2005: 53)

Rajah 4 merupakan salah satu cabutan skor notasi posisi penari oleh dihasilkan oleh Ahmad Omar bagi gerak Campak Lenggang Sambut Gong (2005: 89). Dapat diperhatikan bahawa hitungan-hitungan masa pelaksanaan gerak dinyatakan pada halaman yang sama, berpadanan dengan nama rajah dan terpisah daripada notasi.

Dengan merujuk skor pada Rajah 4, beberapa dapatan diperoleh dan cadangan susulan dilakukan untuk pembacaan skor yang lebih meyakinkan. (1) Penggunaan model (penari), kostum dan peralatan yang konsisten - Ketidakseragaman dalam penggunaan model, kostum dan peralatan dalam menotasikan satu motif gerak yang 


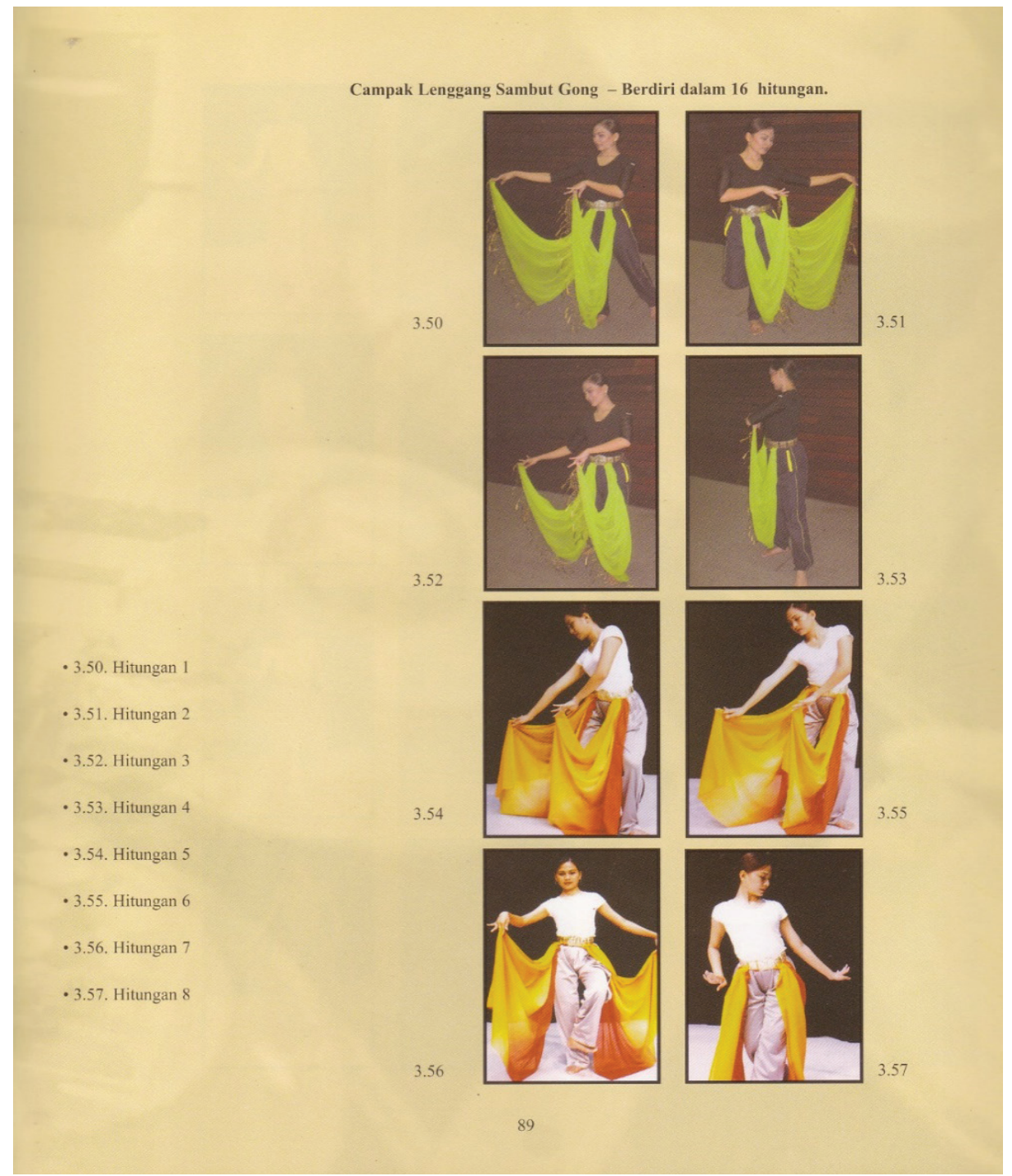

Rajah 4 Notasi posisi penari Campak Lenggang Sambut Gong.

(Sumber: Ahmad Omar, 2005: 89)

sama boleh mengelirukan pembaca. Kostum turut dicadangkan supaya menggunakan baju latihan yang boleh menampakkan liuk badan, terutamanya untuk tari-tari istana Melayu yang amat menekankan gaya liuk badan. Kontras antara warna baju latihan dan warna latar belakang foto diperlukan supaya penari lebih ditonjolkan. (2) Sudut pengambilan foto yang konsisten dan menyeluruh - Sebagai contoh, gerak angkat 
kaki kanan dalam Foto 3.51 (Rajah 4) adalah tidak kelihatan, dan posisi gerak kaki telah "dipotong" dalam Foto 3.57 (Rajah 4). Sudut pengambilan foto boleh bertukar sekiranya ciri-ciri dominan gerak tidak dapat dipaparkan dengan sudut yang sama. (3) Penerangan gerak penghubung - Pelaksanaan gerak penghubung boleh dijelaskan melalui deskripsi yang mudah, atau lakaran anak panah yang boleh menunjukkan laluan pergerakan. Sebagai contoh, pembaca bebas melakukan gerak penghubung dari posisi Foto 3.50 ke Foto 3.51 (Rajah 4), sama ada kedua-dua lengan hayun ke

\section{NAMA RAGAM : KUIS PUSING \\ PERGERAKAN PERTAMA}

POSISI TANGAN

Wanita: Kedua-dua belah tangan memegang bakul aras pinggang.

Lelaki: Kedua-dua tangan diletakkan di belakang aras pinggang.

POSISI KAKI :

Wanita: Tiada pergerakan dalam kiraan 1,2

Kaki kanan membuat gerak kuis ke kanan dan kiri dalam kiraan 3,4,5,6 (kiraan laju). Kaki kanan melangkah ke depan dan kaki kiri langkah bersilang dengan kaki kanan 7,8

Lelaki: Tiada pergerakan dalam kiraan 1,2. Kaki kanan membuat gerak kuis separuh bulat dalam kiraan $3,4,5,6$. Kaki Kiri membuat gerakan kuis ke kiri sambil pusing $360^{\circ}$ ikut arah kiri dalam kiraan 7,8 .

POSISI BADAN :

Wanita \& Lelaki: Aras rendah (merendah)

PERGERAKAN KEDUA

(PEREMPUAN)

POSISI TANGAN :

Wanita: Tangan kiri ditegakkan 45 darjah ke atas sebelah kiri dalam kiraan 5,6,7. Tangan kanan ditegakkan $45^{\circ}$ ke bawah sebelah kanandalam kiraan 7. Kembali ke posisi mula dalam kiraan 8. Lelaki: Tangan kanan membuat gerakan kaut ke dalam dalam kiraan 7,8

POSISI KAKI

Wanita: Kaki kanan melangkah dan membuat pusingan $360^{\circ}$ dengan kiraan $1,2,3,4$. Kemudian kedua-dua kaki dijengketkan dalam kiraan 5,6. Duduk mencangkung dalam kiraan 7 dan berdiri kembali pada kiraan 8.

Lelaki: Gerakan kunang-kunang mabuk / silang kaki dalam kiraan $1,2,3,4,5,6$. Duduk cangkung dalam kiraan 7,8

POSISI BADAN

Wanita: Dalam keadaan aras normal dalam kiraan $1,2,3,4$. Aras tinggi dalam kiraan 5,6. Aras rendah dalam kiraan 7.

Lelaki: Aras normal

Aras bawah dalam kiraaan 7,8.

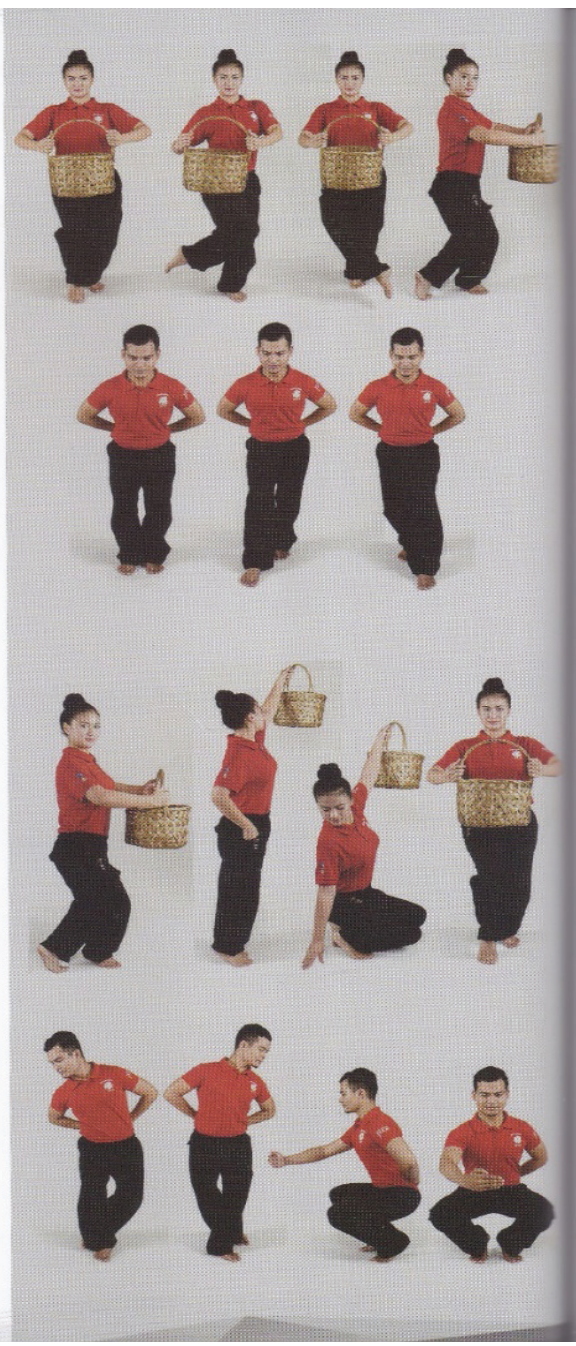

Rajah 5 Ragam kuis pusing dalam notasi inspitari. (Zuriah, 2016b: 32) 
bawah (seperti bentuk U), hayun ke atas (seperti pelangi), ataupun hayun depan. Penjelasan gerak penghubung melalui deskripsi atau anak panah boleh meyakinkan pembaca.

Jabatan Kebudayaan dan Kesenian Negara ${ }^{5}$ (JKKN) sebagai salah satu badan berkanun persekutuan bertanggungjawab untuk menyemarakkan kegiatan seni, budaya dan warisan negara demi meningkatkan kesejahteraan dan perpaduan negara. Dalam perkembangan sistem notasi vernakular yang berbentuk notasi posisi penari, JKKN sememangnya memainkan peranan yang amat penting terutamanya melalui penerbitan naskhah modul (Mardiana, 2015; Zuriah, 2016a, 2016b, 2016c; Mohd Zin \& Zuriah, 2015). Selain daripada menerbitkan modul repertoir tari tradisi Melayu, JKKN adalah amat berminat untuk menerbitkan modul karya gubahan tari baharu khususnya daripada Festival InspiTari dan Kejuaraan Tari Kanak-kanak Malaysia. Kedua-dua acara tari anjuran JKKN ini merupakan platform persembahan yang menggalakkan pengkaryaan berdasarkan elemen budaya alam tempatan - pelbagai permainan, persembahan tradisional, kegiatan domestik, legenda atau dongeng, ciriciri geografi dan demografi di negeri masing-masing telah diterokai, dimanipulasi dan divisualisasikan berlandaskan acuan estetik tari tradisi. Dengan ini, JKKN menggalakkan kajian etnografi dan rekonstruksi terhadap amalan gerak tempatan yang semakin dilupakan, serta memberangsangkan perekaan ragam atau tari baharu yang menonjolkan identiti tempatan. Repertoir tersebut lazimnya dimodulkan supaya boleh terus dilangsungkan. Bukan sahaja untuk negeri masing-masing, tetapi juga memperkaya dan mempelbagaikan khazanah seni tari di Malaysia. Sistem notasi posisi penari JKKN lazimnya ditambah dengan deskripsi gerak supaya melengkapkan informasi pergerakan (Rajah 5). Amalan pembinaan modul tari pascafestival bukan sahaja menjadi pengkajian semula kraf komposisi sendiri dalam kalangan artis budaya JKKN, malah juga merupakan semakan semula terhadap pembangunan sistem notasi posisi penari dari aspek penjelasan gerak dan kemesraan penggunaannya.

\section{Pelan Pola Lantai (Floor Plan)}

Pelan pola lantai dilakarkan untuk menggambarkan kedudukan dan laluan para penari di atas pentas, yang dilihat daripada pandangan atas. Pelan pola lantai "membekukan" kedudukan terakhir penari demi mempamerkan sesuatu corak atau formasi, serta melakarkan laluan pengalihan penari. Pelan pola lantai merupakan maklumat tambahan bagi skor notasi supaya pembaca boleh mengetahui arah yang perlu ditujui, atau kawasan yang perlu diliputi semasa melakukan pergerakan lokomotif. Pelan pola lantai adalah amat sesuai untuk mencatatkan ragam tari Melayu 


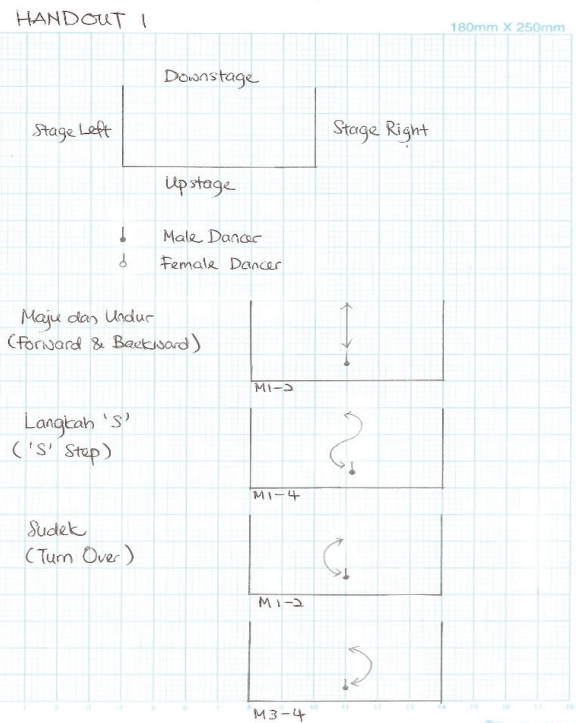

Rajah 6 Pelan pola lantai yang menunjukkan laluan (Sumber: Koleksi peribadi).

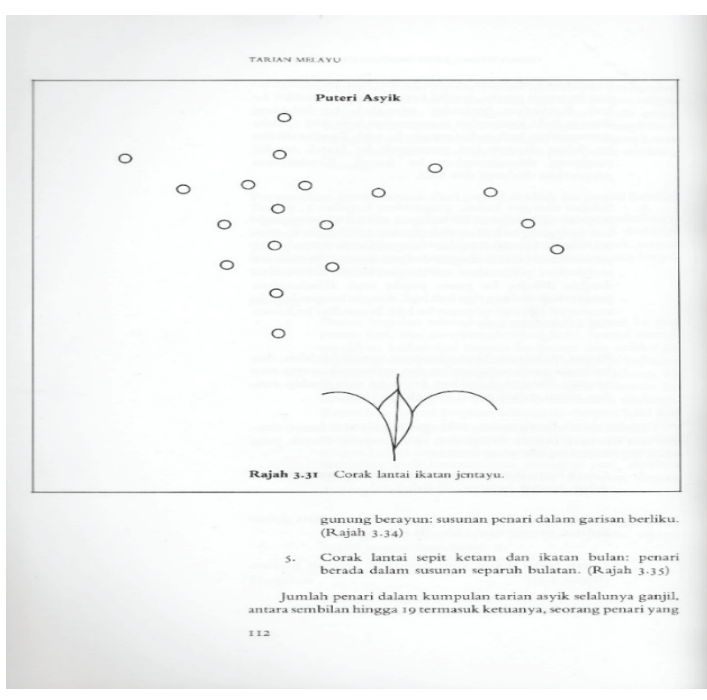

Rajah 7 Pelan pola lantai yang menunjukkan kedudukan terakhir ensembel (Mohd Ghouse, 1994: 112).

yang menekankan bunga perjalanan, seperti Langkah S atau Langkah L dalam Inang (Rajah 6).

D’Cruz (1979), Mohd Ghouse (1994), Mardiana (2015) dan Siti Hanim (2017) melakarkan pelan pola lantai pada naskhah pengajian tari masing-masing. D'Cruz dan Siti Hanim mengaplikasikan pengetahuan Labanotasi dalam pelan pola lantai mereka, seperti pin putih untuk menunjukkan penari wanita; pin hitam untuk menunjukkan penari lelaki; arah hujung pin yang tajam melambangkan arah hadapan penari; serta anak panah yang menggambarkan laluan perjalanan penari. Mohd Ghouse (Rajah 7) dan Mardiana pula menggunakan simbol bulatan untuk menunjukkan kedudukan penari yang membentuk formasi tertentu. Secara umumnya, formasi pentas tari Melayu dalam penaskhahan lazimnya mempunyai nama yang indah, puitis serta berkaitan dengan fauna dan flora alam, seperti Ikatan Jentayu, Ikatan Bebaling, Ikatan Naga Berjuang, Sepit Ketam, Pucuk Rebung, Kayu Manis, Bunga Lawang dan lain-lain lagi. Formasi yang sama mungkin mempunyai nama yang berbeza mengikut guru yang berbeza. Pelan pola lantai dicadangkan untuk menambahkan 
petunjuk bagi menjelaskan bahagian depan dan belakang ruang pentas, yang boleh mengelirukan pemahaman arah kanan dan kiri.

\section{KESIMPULAN}

Artikel ini menerangkan fenomena penciptaan dan penggunaan sistem notasi vernakular untuk tari Melayu berdasarkan tiga pendekatan ilustrasi yang lazimnya digunakan, iaitu (1) Notasi tapak kaki yang sesuai digunakan untuk mentranskripsikan manipulasi gerak kaki seperti Zapin; (2) Notasi posisi penari yang memudahkan pembaca mempelajari sesuatu tari melalui kaedah imitasi "bentuk - gerak - bentuk"; serta (3) Pelan pola lantai yang memaparkan gambaran yang jelas tentang kedudukan dan laluan penari di pentas daripada pandangan. Pelbagai skor telah dilampirkan untuk menerangkan keberkesanan dan kebolehan komunikasi bagi ketiga-tiga pendekatan notasi ilustrasi.

Pembangunan sesuatu sistem notasi vernakular memerlukan dana kewangan dan tenaga pekerja yang mahir. Kos pembinaan skor biasanya hanya dapat ditaja atau dibiayai oleh badan-badan kerajaan yang bertanggungjawab dalam memartabatkan kegiatan seni budaya, seperti YWJ yang membangunkan sistem notasi tapak kaki dan JKKN yang mengembangkan sistem notasi posisi penari. Dalam pada itu, pembangunan sistem notasi YWJ amat dipengaruhi oleh pengetahuan Labanotasi. Walaupun dengan proses yang perlahan, kedua-dua YWJ dan JKKN tetap mengadakan semakan dan penambahbaikan dari semasa ke semasa terhadap sistem notasi vernakular ciptaan mereka, serta ingin mengurangkan kebergantungan kepada kaedah pengajaran dan pembelajaran konvensional yang berlandaskan penurunan secara lisan. Dapatan daripada lapangan juga menunjukkan bahawa kedua-dua agensi ini sedang melakukan pelbagai percubaan untuk meningkatkan tahap mesra penggunaan sistem notasi vernakular mereka bukan sahaja untuk tujuan pemeliharaan dan pelestarian tari, tetapi juga untuk meningkatkan autoriti profesionalisme agensi masing-masing. Memiliki sistem notasi vernakular yang tersendiri memberi implikasi bahawa mereka juga menuntut kuasa ketuanpunyaan terhadap sesuatu genre tari.

Mengetahui perkembangan sistem notasi vernakular tari Melayu tempatan adalah penting untuk mengisi kekosongan sejarah pengajian tari tempatan yang lebih mementingkan penerangan dan penyelidikan sesuatu genre tari dari perspektif etik dan emik. Dengan erti kata lain, suara atau peranan amalan sistem notasi vernakular tidak tercatat dalam arus penyelidikan pengajian tari tempatan, walaupun sistem vernakular kerap direka dan digunakan untuk membahaskan gerak tari. Artikel ini ingin menghargai kebijaksanaan pencipta dan pengamal sistem notasi vernakular dalam aspek penginstitusian dokumentasi dan promosi warisan seni tari. 
Sebagai seorang pengajar Labanotasi, pengkaji sering dijemput untuk menjadi notator bagi calon-calon pascasiswazah program tari. Biasanya mereka ingin melampirkan skor Labanotasi dalam tesis mereka atas nasihat penyelia, walaupun kebanyakan mereka telah mentranskripsikan seluruh atau sebahagian tari dalam notasi tapak kaki atau notasi posisi penari. Hal ini menunjukkan bahawa skor Labanotasi sememangnya masih dipilih untuk memaparkan tahap intelektual yang lebih tinggi - sekurang-kurangnya dalam kalangan penyelia mereka - tanpa melihat kepada kos dan beban usaha penotasian yang amat berat, serta tidak meneliti kepada kerelevanan pilihan ragam atau motif tari yang hanya signifikan kepada komuniti pengamal. Artikel ini ingin mencadangkan bahawa tiada satu sistem notasi yang bersifat mutlak. Pelbagai simbol, konsep pergerakan dan pengetahuan transkripsi gerak boleh dimanipulasikan untuk kegunaan sendiri, berdasarkan keutamaan penotasian ciri-ciri dominan sesuatu tari. YWJ dan JKKN sebagai pengasas notasi bersikap terbuka dan fleksibel untuk menerima pelbagai pengetahuan untuk menyempurnakan sistem notasi tersendiri, tanpa berniat untuk membangunkan satu sistem notasi yang bersifat universal, namun lebih mendekati golongan akar umbi.

Artikel ini juga mencadangkan bahawa sistem notasi vernakular mungkin boleh mengatasi halangan penyampaian bahasa, dan dijadikan sebagai salah satu cara untuk membolehkan para peminat tari yang terdiri daripada berbilang kaum dan latar belakang dapat menikmati sensasi dan keseronokan pergerakan semata-mata (pure movement) bagi genre tari Melayu, tanpa memikul beban atau tanggungjawab "interaksi budaya" yang lebih mengutamakan pemahaman melalui perbahasan teori. "Tak kenal maka tak cinta" - dalam konteks artikel ini, pengalaman pergerakan tari Melayu yang boleh diperoleh melalui pembacaan skor notasi vernakular boleh dijadikan langkah yang pertama untuk mengenali budaya dan nilai estetik Melayu.

\section{NOTA}

1 Gestur atau gerakan bahagian tangan dan lengan yang simbolik, dan merupakan salah satu ciriciri yang penting dalam tarian tari klasik India dan ekspresi teatrikal. Sistem gerakan mudra dipercayai diperkembangkan daripada upacara ritual yang memerlukan aksi gerak dan pembacaan mantra.

2 Hanamichi, dalam persembahan Kabuki Japan, merupakan satu platform laluan yang menghubungkan kawasan penonton ke pentas utama. Platform tersebut membolehkan para pelakon masuk dan keluar dari pentas dan panggung, serta juga boleh dijadikan kawasan persembahan selain sebagai pentas utama.

3 http://www.ywj.gov.my/

4 Kinesfera merupakan ruang imaginasi yang berbentuk bulatan di sekeliling badan yang pinggiran bulatannya boleh dicapai oleh lengan dan kaki.

5 http://www.jkkn.gov.my/ 


\section{RUJUKAN}

Ahmad Omar, H.I. (2005). Joget Gamelan Terengganu \& Pahang: Penerus tradisi seni persembahan istana Kesultanan Melayu Melaka. JKKN Ministry of Cultural Arts and Heritage Malaysia.

Daud, H. (1965). Chara menari Ronggeng dan Mak Inang. Penerbitan Federal.

D’Cruz, M.F. (1979). Joget Gamelan: A study of its contemporary practices (Unpublished master's thesis). Universiti Sains Malaysia, Pulau Penang, Malaysia.

Guest, A.H. (2005). Labanotation: The system of analyzing and recording movement (4th ed.). Routledge.

Guest, A.H. (1984). Dance notation: The process of recording movement on paper. Dance Book Ltd.

Mardiana, I. (2015). Modul pengajaran dan pembelajaran Mak Yung. JKKN.

Md. Ismail, Z., Nur Najjwa, M.A., Hamidah, I., Leng, P.G., \& Ismail, B. (n.d.). Pengisian buku kaedah pembelajaran Zapin negeri Johor tahun 2014 (Unpublished manuscript). YWJ.

Mohd Anis, M.N. (2014). Between orality and dance notation: Reviving Zapin dance and music as cultural heritage. In Fiskvik, A.M. \& Stranden, M. (Eds.) (Re)Searching the field: Festchrift in honour of Egil Bakka. Fagbokforlaget.

Mohd Anis, M.N. (1993). Zapin: Folk dance of the Malay world. Oxford University Press.

Mohd Ghouse, N. (1979). Dance and music of desa performing arts of Malaysia (Unpublished doctoral dissertation). University of Indiana, USA.

Mohd Ghouse, N. (1994). Tarian Melayu. Dewan Bahasa dan Pustaka, Kementerian Pendidikan Malaysia.

Mohd Zin, M.S. \& Zuriah, M. (coordinators) (2015). Modul InspiTari 2013 siri 1: Pilihan tarian-tarian InspiTari 2013. JKKN.

Royce, A.P. (1977). The anthropology of dance. Indiana University Press.

Siti Hanim, Y. (Ed.) (2017). Seni Tari: Sekolah Seni Malaysia tingkatan 1. Dewan Bahasa dan Pustaka.

YWJ (2013). Bahan Rujukan Kaji Selidik Zapin dan Muzik Tahun 2013 [Report]. YWJ.

YWJ (n.d.). Lakaran Gerak Zapin Johor [Training course booklet]. YWJ.

Zuriah, M. (koordinator). (2016a). Modul InspiTari 2013 siri 2. JKKN.

Zuriah, M. (koordinator). (2016b). Modul InspiTari 2014. JKKN.

Zuriah, M. (koordinator). (2016c). Modul InspiTari 2015. JKKN. 